\title{
Erratum to: The Convergence of the Fundamental Rights Protection in Europe
}

\author{
Rainer Arnold \\ (C) Springer Science+Business Media Dordrecht 2016 \\ R. Arnold (ed.), The Convergence of the Fundamental Rights Protection \\ in Europe, Ius Gentium: Comparative Perspectives on Law and Justice 52, \\ DOI 10.1007/978-94-017-7465-9
}

DOI 10.1007/978-94-017-7465-9_13

The chapter "Human Dignity and European Constitutionalism: Flatus Vocis or Ratio Decidendi?" was unfortunately omitted from the original version of this book. Now the chapter is added as chapter 12 at the end of the book after the chapter 11 "Access to Services of General Economic Interest Under Article 36 of the Charter of Fundamental Rights EU and the National Law."

The online version of the updated book can be found at http://dx.doi.org/10.1007/978-94-017-7465-9 